\title{
Reconciliation as a Threat or Structural Change? The Truth and Reconciliation Process and Settler Colonial Policy Making in Finland
}

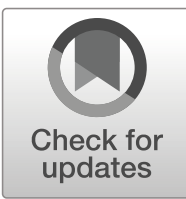

\author{
Rauna Kuokkanen ${ }^{1}$
}

Published online: 25 May 2020

(C) The Author(s) 2020

\begin{abstract}
The Sámi have long desired a public process to examine and expose the Nordic states' colonial, assimilationist practices and policies, past and present, toward the Sámi people. This article considers the truth and reconciliation process in Finland, assessing it in light of recent legislative and other measures. Employing settler colonial theory, it argues that reconciliation, although seemingly progressive, signifies a continuation of colonialism unless the state terminates its current approach of overlooking Sámi rights. The article concludes with a discussion of structural reconciliation and justice and considers some concrete measures for structural change in order for the reconciliation process to be valid and successful in Finland.
\end{abstract}

Keywords Reconciliation · The Sámi people · Settler colonial theory · Policy-making · Indigenous peoples $\cdot$ Finland $\cdot$ Structural justice

The Sámi people in the Nordic countries are among those Indigenous peoples who have recently embarked on the path of truth and reconciliation process with their respective colonizer states. In Norway, a Truth and Reconciliation Commission was established in 2018 to examine past injustices committed against the Sámi and Kven peoples by the Norwegian state. ${ }^{1}$ In Finland, the main Sámi political bodies approved the proposal for a commission in late 2019, which means that as soon as the commissioners are in place, the commission will commence its work. In Sweden, public debate about a truth and reconciliation process has been ongoing for over a decade. The Swedish church initiated an inquiry into a reconciliation commission in 2006 . The government rejected

\footnotetext{
${ }^{1}$ The Kven are a Finnish speaking minority in Northern Norway who were also targeted by the assimilationist policies of the state in the nineteenth century.
}

Rauna Kuokkanen

Rauna.kuokkanen@ulapland.fi

1 Faculty of Social Sciences, University of Lapland, Yliopistonkatu 8, PO Box 122,

96100 Rovaniemi, Finland 
the proposal to establish a commission in 2018 but has since agreed to negotiate the parameters of a commission with the Sámi Parliament, scheduled to take place in 2020.

The Sámi have long desired for a public process and an engagement to examine and expose the Nordic states' colonial, assimilationist policies toward the Sámi people. Overall, there is very little public knowledge and awareness about the Sámi, and their society, colonial history, culture or rights in the Nordic countries. Holding the Canadian TRC particularly as a model, Sámi leadership considers the reconciliation process as a way to improve the state-Sámi relations and empower and strengthen Sámi society. Many Sámi agree that there is a pressing need to identify and discuss the historical and present-day wrongs by the state. These include the history of assimilation, dispossession of land and resources, legacy of residential schools, language and identity theft, forced conversion to Christianity, destruction and defamation of Sámi spirituality and sacred sites, and active engagement in racial biology research as recently as in the late 1960s in which Sámi were measured and categorized.

Many Sámi share a sentiment that the Sámi experience of colonialism is almost entirely unknown to Nordic states and mainstream population, and often also to the Sámi themselves. Yet many doubt the Government of Finland's intentions of reconciliation. Reconciliation cannot proceed, as the former president of the Sámi Parliament in Finland Tiina Sanila-Aikio suggested, if Indigenous rights are being weakened by actively advancing development initiatives such as logging, mining, mass tourism and infrastructure plans (Ranta 2018). The questions asked by many Sámi include, how can we trust the state as a party to reconciliation while for the past several years, it has been backtracking on (already limited) Sámi rights, legislation and established state obligations toward the Sámi? How can the state genuinely engage in reconciliation while pushing for aggressive and extensive land use and development plans considered detrimental to the interests of the Sámi, particularly to traditional livelihoods?

This article examines the context in which a truth and reconciliation commission (TRC) for matters concerning the Sámi has been proposed and discussed in Finland. Does reconciliation represent a subtle colonizing manoeuvre or does it carry the potential for a radical departure from the current repressive approach to Sámi rights by the state? The article shows that in light of the current political climate, Sámi concerns about reconciliation as continuation of colonialism (in disguise of progressive politics) are warranted. As one of the first scholarly engagements with settler colonial theory in examining contemporary Sámi policy, the article establishes the continuity between the apparent oppositional politics of exclusion and inclusion in Scandinavia. It suggests that without a commitment to a structural approach to justice, reconciliation in Finland will indeed mark an extension of ongoing settler colonialism.

The article is in three parts. The first part begins with an overview of the final report of the hearings held as part of the TRC preparatory process. As the first extensive documentation of Sámi views of the proposed truth and reconciliation process in Finland, the report is used as a key source in discussing reconciliation in relation to Sámi concerns and the state's approach to Sámi affairs. The article then moves on to consider the reconciliation process in Finland, and its agreed-upon mandate and objectives. In the second part, the article considers settler colonialism in Finland and examines a number of recent cases in which the state's legislative measures have weakened, rather than supported, Sámi rights and self-determination in Finland. This analysis reveals what Alissa Macoun and Elizabeth Strakosch call "the complex and 
subtle colonizing movements of progressive inclusion" (Macoun and Strakosch 2013, p. 430). The article concludes with a discussion of the theory of structural reconciliation and justice and considers the key structural changes that need to take place in Sámistate relations in order for the TRC process to be meaningful in Finland.

\section{Main Findings of the 2018 Hearings Report}

Commissioned by the Prime Minister's Office, the hearings in 18 Sámi communities and five cities took place in May-June 2018 as part of the preparatory process leading to the possible establishment of a TRC in Finland. ${ }^{2}$ The report outlines Sámi views of the potential TRC process, the mandate and commissioners. It concludes that the Sámi regard the TRC process as important and timely, and asserts that there is a clear need to provide a venue for Sámi to discuss their experiences of assimilation and oppression. There is a broad agreement on the significance of collective healing and education about the colonial history and Sámi experiences thereof. Many Sámi themselves know little of their own history for it has not been taught in schools. The report also reveals a deep-seated mistrust of the government intentions for reconciliation in a political context which many describe as increasingly repressive. Many are sceptical of the state's motives and sincerity. Some openly question the double standard of the state while others are bemused by the apparent speaking in two tongues (Juuso 2018).

The report further raises the concern of a growing backlash against the Sámi and their rights claims, particularly with respect to legislation and policy. Racism and online hate speech have proliferated, and anti-Sámi sentiments in the Finnish society have intensified in the past decade. This has led many Sámi to feel that their very existence as Sámi individuals and as a people is being threatened by the state and mainstream society. Some feel they have lost everything as the result of colonialism, from language, culture and identity to land and spirituality. In addition to general mistrust, some fear that once more the Sámi people and their issues are being studied without guarantees that anything will change for better. These Sámi fear they will be obligated to participate in the work of the commission as informants and publicly talk about their most painful experiences and deepest traumas - many of which have never been expressed even in private-with no assurances it amounts to anything except more negative fallout (Juuso 2018).

In terms of the possible mandate, the report suggests that it is of utmost importance for Sámi that if a commission is established, it should focus squarely on Sámi-state relations both past and present rather than limiting the scope to a single issue such as Sámi boarding school experiences. There is a shared sentiment that the ongoing and, in some regards, intensifying practices of assimilation of the Sámi people must be at the centre of the TRC process. Given how recent changes to land and resource use legislation and planning disregard Sámi rights and right claims, suggestions regarding to the commission's mandate frequently related to land use. The difficulty of maintaining and practicing Sámi culture is linked to the elimination of Sámi rights to land, water and resources, which in turn has made it difficult to practice traditional livelihoods such as reindeer herding and fishing. The report points out that Sámi rights to

\footnotetext{
${ }^{2}$ In addition to the hearings, it was possible to submit views via email during the hearing period.
} 
reindeer herding or fishing have no protection in Finland. What is instead actively supported and promoted by the government - through its decision-making, policies, legislation as well as public opinion-includes extractive industries, infrastructure initiatives and tourism, the scope of which is increasingly global and skyrocketed in the past few years (Juuso 2018).

\section{Progressive Mandate, Ambiguous Motive: Reconciliation Process in Finland}

Truth and reconciliation commissions are considered part of transitional justice often established in a post-conflict period to investigate human rights violations perpetrated by governments. For many Indigenous peoples, TRCs represent a formal mechanism with which to expose and publicly assess the colonial history, policies of assimilation, dispossession and other wrongdoings of the state in order to establish the truth and to provide a platform for the renegotiation of Indigenous politics (e.g., Corntassel and Holder 2008; Lightfoot 2015; Thisted 2017). Research on reconciliation and Sámi-state relations is very limited and focuses on the TRC processes in Norway or Sweden (Barrios 2017; Björn and Sjögren 2019; Griffiths 2018; Hall 2016; Mustonen 2016).

In Scandinavia, the Sámi Parliamentary Council (a joint body of the three Sámi Parliaments) issued a statement on the Sámi National Day February 6, 2017, encouraging the Nordic countries to establish truth and reconciliation commissions to examine Sámi-state relations. Soon after the Sámi Parliamentary Council's statement, the Executive Council of the Sámi Parliament in Finland met with then prime minister Juha Sipilä. It was decided that the parties will embark on the preparatory process toward a TRC. Accordingly, a seminar with international and Sámi speakers was held in February 2018 in Anár/Inari to discuss the objectives and work of truth and reconciliation commissions. The closing panel of the seminar, in which Sámi spoke about their personal experiences of assimilation, racism and the need for bringing such experiences out to open, was a deeply moving encounter with raw emotions rarely witnessed publicly in Sápmi. The panel gave everyone a taste what a TRC process would entail but was also met with hostility. ${ }^{3}$

The negotiations concerning the mandate of a truth and reconciliation commission began in February 2019 between the representatives of Sámi Parliament, Skolt Sámi Village Council ${ }^{4}$ and the Government of Finland. The negotiations were completed in late October 2019, and both the Sámi Parliament and Skolt Sámi Village Council approved the mandate in their plenaries soon after.

The mandate for the proposed TRC in Finland is unquestionably progressive. The purpose of the TRC is to recognize and assess historical and contemporary discrimination against the Sámi, including state assimilation policies and rights violations, and

\footnotetext{
${ }^{3}$ Some individuals in the audience later dismissed and ridiculed the statements of the three young Sámi women in social media as "poor drama". The Sámi women's experiences and stories were questioned along the lines, "these young Sámi women have not experienced discrimination". The fact that the panelists and the interpreter were crying was viewed as a prearranged show to mislead the international guests "while the oppression of the real Indigenous people was not discussed" (Juuso 2018, p. 29).

${ }^{4}$ The Skolt Sámi Village Council is a traditional Skolt Sámi governing body, recognized in the Skolt Sámi Act (1955). Today, the Skolt Sámi Village Council is a local consultative and deliberative authority.
} 
to examine how they impact the Sámi and their society in the present day. The TRC will propose how relations between the Sámi and the state as well as among the Sámi people could be advanced. Further, the truth and reconciliation process will increase awareness about the Sámi as the Indigenous people in Finland and in that way, advance the positive development of Sami-Finnish relations. As the result of the truth and reconciliation process, the mandate stipulates, the Finnish state will take responsibility and together with the Sámi Parliament, Skolt Sámi Village Council and other Sámi actors strengthens the implementation of Sámi rights in Finland (Valtioneuvoston kanslia 2019).

According to the proposed objectives of the TRC, a shared understanding of the discrimination faced by the Sámi will be established by collecting Sámi people's experiences of actions of the state and state authorities. In this way, the Commission will create a foundation for reconciliation between the Sámi and the Finnish state, for structural change and interaction based on trust which will support the Sámi in their endeavours to maintain and develop their own language and culture. This includes traditional Sámi livelihoods rooted in the relationship with the land and water. The Commission is also required to consider central factors affecting the implementation of Sámi rights, such as climate change. Finally, the work of the Commission is expected to help addressing traumas Sámi have at the individual level and as a people (Valtioneuvoston kanslia 2019).

It is clear why many Sámi want a truth and reconciliation process. They want a public process with the state in which the historical and contemporary wrongs associated with colonialism are exposed and their consequences at the individual and collective levels discussed. Since gaining independence in 1917, Finland has never had explicit colonial or discriminatory policies or legislation regarding the Sámi. Sámi policy has always been ad hoc, with an unstated approach according to which the Sámi are not a distinct people but rather, Sámi-speaking Finns who should be assimilated into the Finnish body politic particularly through education (Lehtola 2005; Nyyssönen 2011). The Sámi in Finland have thus been at the mercy of disorganized policy and decision-making by various ministries and state authorities which often conflict with one another. ${ }^{5}$ Compounded with a lack of public discourse about such practices or their effects, this has led to experiences of negating, disparaging and threatening Sámi identity and belonging, often internalized as individual shortcomings and shame. With TRC processes, the Sámi want accountability from the state.

What is less clear is why the Government of Finland has agreed to embark on a truth and reconciliation process, given its sketchy track record of acting upon the Sámi Parliament's requests. As the former president of the Sámi Parliament, Pekka Aikio, has noted, while some Sámi petitions have been taken into consideration, "by far the majority have been ignored" (Aikio 1987, p. 97). The common pattern of legislative initiatives collapsing at the vote of the national parliament (if not sooner) is illustrative of the weak political instruments at the disposal of the Sámi Parliament and the Sámi in general in Finland (Lehtola 2005). Until Prime Minister Sipilä's resignation in early 2019, the TRC process remained largely his personal initiative, and did not enjoy a broad support or awareness either in the Government or the Parliament. Not

\footnotetext{
${ }^{5}$ Ad hoc development of political solutions to address especially the question of the right of the Sámi to their territories has also taken place in Norway (see Selle 2011).
} 
surprisingly, many Sámi viewed the TRC process as the former prime minister's legacy project (Juuso 2018). With the new government and prime minister, the rationale of the state is as ambiguous as before. ${ }^{6}$ Some Sámi suspect that the state interest in the TRC process stems from the longstanding deadlock pertaining to the legal definition of Sámi, which for many appears as the "Sámi fighting with one another" or worse, exclusionary politics on behalf of the Sámi people and their institutions against the socalled "unrecognized Sámi” (Juuso 2018).

\section{Settler Colonial Theory and Settler Colonialism in Finland}

Classical colonialism and settler colonialism are two distinct forms although they frequently coexist and "reciprocally define each other" (Veracini 2010, p. 4). Classical colonialism signifies a relation of external domination by a minority over a native majority population, governed from a distant imperial centre. It is premised on the persistent reproduction of mutually exclusive hierarchies in which the dominant group maintains its superiority (Balandier 1966; Osterhammel 1997; Veracini 2010). As a distinct political formation, settler colonialism is informed and driven by sustained "logic of elimination" that seeks to remove Indigenous peoples to gain access to their territories. It is characterized by inherently dynamic circumstances where Indigenous people (together with "exogenous Others") "progressively disappear in a variety of ways: extermination, expulsion, incarceration containment, and assimilation for indigenous peoples (or a combination of all these elements)" (Veracini 2010, p. 16-17).

The theory of settler colonialism as a structure and logic of elimination has been greatly influential and continues to inform the analysis of colonial configurations and power in the field of critical Indigenous studies (cf. Byrd 2014; Kauanui 2016; Speed 2017). Settlers came to stay, imposing their sovereignties and jurisdictions over existing ones. Obtaining the land for the purposes of establishing a new society invariably requires getting rid of and replacing Indigenous peoples and their societies with settler structures and institutions (Wolfe 2006). Settler colonialism is also characterized by its persistent drive to naturalize its ongoing existence and domesticate settlers as native. Through this naturalization, it seeks to "challenge the meaningful existence of Indigenous life and locate colonial dominances in the past" (Strakosch 2015, 50). The settler colonial system thus becomes the taken-for-granted and self-evident background and reality for settler existence and their political and legal structures (Rifkin 2013).

Settler colonialism's impact is not felt only in Indigenous or settler societies and territories, but as Scott L. Morgensen contends, it has conditioned and "directly informs past and present processes of European colonisation, global capitalism, liberal modernity and international governance" (Morgensen 2011, p. 53). Besides a logic dispossession and form of governmentality, settler colonialism operates through discourses that legitimize its existence and institutions, including narratives according to which "the settler state is universal and benevolent, and that colonialism is in the interests of Indigenous people, has ended, or is inevitable" (Macoun and Strakosch 2013, p. 433). At the affective level, settler colonialism functions through certain emotions that support settler colonial narratives, such as perception of authority over definitions of

\footnotetext{
${ }^{6}$ The government has changed in Finland twice after Sipilä's cabinet of 2015-2019.
} 
Indigeneity, fear and suspicion of Indigenous people, anger and frustration over, or feeling threatened by Indigenous claims (Macoun and Strakosch 2013). Settler colonial effects of guilt and complicity are often mitigated through denial and "moves to innocence" (Grey and James 2016; Maddison 2011; Nagy 2012; Tuck and Yang 2012).

Considering the basic premises of settler colonialism - settlers coming to stay and Indigenous land dispossession - it is clear that settler colonialism is a structure characterizing Sápmi, both in the past and present. The examination of the current policies and legislation vis-à-vis the Sámi in Finland, below, further demonstrates that the Finnish state actively engages with a logic of elimination toward the Sámi and thus, is a settler state. ${ }^{7}$ Settler colonialism, however, occurred differently in different regions. The way in which settler colonialism played out historically in Sámi territories within the kingdom of Sweden (i.e., northern parts of present-day Finland and Sweden) is unique compared to most other Indigenous peoples.

In the past, Sámi families privately owned their territories they used for hunting, fishing and reindeer herding. This ownership was fully accepted and recognized by the local and national authorities and recorded in hundreds of written court proceedings from the seventeenth century to nineteenth century. These and other historical documents such as land tax registries demonstrate that the Sámi ownership of their territories corresponded to that of the farmers (or settlers) (Korpijaakko 1989).

At first, the so-called Lapp livelihoods of fishing, hunting and reindeer herding were the only legal forms of land use in Sápmi, demarcated by the so-called "agricultural border" north of which farming or establishment of farms was not allowed. Royal decrees in 1673 and 1695, however, opened up the possibility of farming and cattle breeding above the agricultural border. A central reason for opening up the agricultural boundary for settlers was the discovery of silver and other mining interests which required more labour than was available locally in Sápmi. The decrees stipulated that a settling was allowed only in land areas for which no individual Sámi paid taxes and therefore, was regarded as unused or deserted. The settlers were mandated to stay farmers and cattle breeders and not take up the so-called Lapp livelihoods. In this way, the two livelihoods were intended to keep separate and the Sámi land ownership and livelihoods protected (Korpijaakko 1989).

The initial settlement in the Sámi territory within the kingdom of Sweden did not entail the denial or elimination of Sámi rights. The 1749 decree continued to emphasize the separation of Sámi and settler livelihoods. The enactment of the settlement decrees led to the gradual development of a two-tier property regime. Those practicing the socalled Lapp livelihoods belonged to the traditional Sámi siidas, and the settler farms established a new village system (Saamelaisasian neuvottelukunta 1990). Notably, also

\footnotetext{
7 The question of settler, however, is more complex than in the paradigmatic settler colonial countries. The settlers who historically arrived to Sápmi did not arrive from overseas but from the south of the kingdom (south of the so-called "agricultural boundary"). This raises an interesting question of who counts as a settler today in Finland - are contemporary settlers only those who are descendants of the historical settlers who crossed the farming boundary, or all Finns currently living within the Sámi territory? Yet to be examined in the Nordic context, the question is beyond the scope of this article. The focus of the analysis is on the settler colonialism as a state structure that, through its institutions, seeks to "destroy to displace" (Wolfe 2006, p. 388). Hence, the argument that the Finnish state is settler colonial for the purpose of considering existing policy and legislation does not hinge on the question of who is a settler in Finland.
} 
Sámi were able to settle and become farmers, which many did for a variety of reasons (Lehtola 2002; Nahkiaisoja 2006). Due to the increased settlement, the new property and administrative regime slowly eradicated the siida system, the traditional local Sámi governance structure, starting in the eighteenth century. ${ }^{8}$ At the turn of the 19th and 20th centuries Sámi rights and ownership were no longer upheld or recognized in official state documents although Sámi in Finland paid taxes for their territories until 1924. Since the late nineteenth century, the territories not allocated to settlers and for farming were considered crown land notwithstanding there is no legal proof of any kind demonstrating the transfer of the Sámi territories to the Finnish state (Saamelaisasian neuvottelukunta 1990).

\section{Contemporary Settler Colonial Policy and Legislation in Finland}

While engaging in a truth and reconciliation process, the Government of Finland has actively overlooked Sámi rights and rights claims on a number of fronts. What is particularly striking is the way in which the state has, in the past few years, repeatedly disregarded its own basic legislative obligations toward the Sámi. The Sámi people's right to their culture and language is constitutionally protected in Finland (Sec. 17.3). In addition, there is a legislative requirement for all authorities in Finland to consult the Sámi Parliament "on any far-reaching and significant measure which may have an immediate and specific impact on the status of the Sámi as an indigenous people and which concern the Sámi homeland," including "exploration for, and exploitation of, mineral deposits and gold mining in the country's land and water areas" (Act on the Sámi Parliament, 974/1995, Art. 9.3). Below, I discuss several major cases in which the state's legislative and other measures have undermined and deteriorated, rather than upheld, Sámi rights and self-determination.

In 2016, the amended Act on Metsähallitus (234/2016), the state parks and forest enterprise, was adopted without the approval of the Sámi Parliament or the affected reindeer herders. A state enterprise, Metsähallitus governs the land use of over $90 \%$ of the traditional Sámi territories considered state land. An earlier draft of the act outlined specific regulations with regard to land use in the Sámi region. The so-called Sámi section consisted of two articles which would have provided Sámi culture and traditional livelihoods with a stronger protection vis-à-vis land use planning of "state" lands and waters, a deterioration ban of Sámi culture, and a requirement for Metsähallitus to conduct an impact assessment of the planned activities on Sámi culture and traditional livelihoods and mitigate the possible harms. The deterioration ban stipulated that Metsähallitus' activities must be planned and carried out in a manner that does not significantly reduce Sámi people's possibilities to practice their livelihoods or otherwise maintain and develop their culture. It further included a right to appeal for the Sámi Parliament and Skolt Sámi Village Council if Metsähallitus’ decisions had not

\footnotetext{
${ }_{8}^{8}$ There are other important factors contributing to the elimination of the Sámi land ownership in Finland, including the transfer of the territory of Finland to Russia in 1809, which meant a new legal regime and that the Swedish court proceedings attesting to Sámi land ownership remained in Sweden. Finland gained its independence in 1917 which marked the final departure from the judicial system in place under the rule of Sweden. Further, an allotment process (in Finnish, Isojako) in the early twentieth century did not recognize property rights belonging to those practicing the Lapp livelihoods (e.g., Korpijaakko-Labba 2000).
} 
considered the ban. The "Sámi section" was, however, dropped from the final version, notwithstanding the deep disapproval by Sámi and reindeer herding organizations. The removal was also strongly criticized by the UN Special Rapporteur on the Rights of Indigenous Peoples, according to whom Finland violates the UN Declaration on the Rights of Indigenous Peoples' article 19 that stipulates Indigenous peoples' right for a free, prior and informed consent before new laws and policies are enacted (Aikio 2015).

In 2017, Sámi and their relevant institutions were inadequately involved and consulted in the bilateral negotiations between Norway and Finland regarding the fishing agreement on the Deatnu River at the heart of Sámi region with a long history of traditional Sámi fisheries and fishing practices. Sámi representatives were invited into the negotiation teams but served only as token members. The final versions of the agreement were discussed behind closed doors without Sámi attendance and the government representatives of the two countries held several private meetings. The Sámi members appealed, to no avail, the process and procedures, noting that they did not have a bona fide opportunity to negotiate with the state representatives. Restricting Sámi traditional fisheries twice as much as recreational tourist fishing, the new agreement is considered threatening the survival of Sámi identity, language and culture in the Deatnu Valley, which are seen as inextricable from the river (Aikio et al. 2016; Kuokkanen 2020). The ongoing erosion of a unique fishing culture with its own traditional knowledge and skills will only intensify as the younger generation-many of whom are placed in the category of "tourists" in their own river because they live elsewhere for their studies or work - are deprived of a range of skills and knowledge related to various traditional fishing practices (Holmberg 2018).

Also in 2017, the Finnish Ministry of Transport and Communications requested the Finnish Transport Agency to carry out a feasibility study together with the Norwegian Railway Directory of the construction of a railway from Northern Finland to the coast of Norway. The proposal to build a $€ 3$ billion railway comes as China has expressed interest in enhancing its logistics networks to Europe through the Arctic region and building an "Arctic Silk Road" (Wen 2018). Establishing a railway route to the Arctic Ocean would connect Finland to the global transport system and thus make the country as "a node for Northern European passenger, freight and telecommunications traffic" (Finnish Transport Agency 2018, p. 6). Besides China, a number of Northern Finland municipalities see the initiative as the future of the region. Together, they market the venture as the "Arctic Corridor" and the "a rising cross-border economic area" centred on "growth through Arctic resources", namely oil, gas and minerals as well as access to the Northern Sea Route. ${ }^{9}$ This coincides with a trend over the past decade that has seen mining production doubling in Finland, with Northern and Eastern Finland as the most active regions. In 2018, Finland ranked on the top as the most mining friendly investment in the world, based on its geological wealth for minerals and metals as well as favourable policy environment, good infrastructure and the public sector support in providing many services for the mining industry (Benton 2018).

As the focus of international trade and production has shifted to Asia, the Arctic Railway initiative is seen as part of a much larger initiative to enhance Europe's competitiveness in transport networks. Several alternative routes through Sápmi have been proposed and their feasibility assessed. Two of the route options in particular

\footnotetext{
${ }^{9}$ www.arcticcorridor.fi.
} 
would have major negative impacts on reindeer herding, such as eliminating or fragmenting pastures, disruptions in herding routes, disturbances on grazing, harmful substance residues in reindeer fodder and accidents involving reindeer (Finnish Transport Agency 2018, p. 23). The brief section on "Sámi homelands" in the 2018 Finnish Transport Agency's report is perfunctory, notwithstanding the fact that the impacts of the Arctic railway on Sámi culture and livelihoods would be enormous. The report suggests: "The Arctic Ocean Railway would impact the livelihoods and culture of the Sámi people. The extent of these impacts cannot be evaluated at this stage, except for the aforementioned impacts on reindeer husbandry" (Finnish Transport Agency 2018, p. 23).

The report discusses reindeer herding and the Sámi people separately, and reindeer herding is regarded only as an occupation focused on meat production. The connection between reindeer herding and Sámi culture is not strongly established. Yet when asked about the proposed railway, a young herder in the Anár region replied to a journalist, "I want to continue living from this land just as my ancestors have done for hundreds and hundreds of years. This is a way of life for us - it is not just a job" (cited in Wall 2019). Other herders say that a railway splitting the pastures already shrunken due to other competing land use would be no less than a death sentence to reindeer herding (Saijets 2018). The Sámi Parliament was not initially consulted in spite of the legislated duty to do so. The Parliament requested the Minister of Transport and Communications consultations on several occasions and it still took over 6 months before they were commenced (Suoninen 2017). The former president of the Sámi Parliament Tiina Sanila-Aikio considers it very problematic that the Sámi are not involved in such a massive and far-reaching initiative from the beginning. In her view, the planned Arctic Railway is the reason why the section protecting Sámi rights was dropped in the Metsähallitus Act in 2016. From the vantage point of the Finnish state, it would have given too strong a position for the Sámi regarding land use and planning in the Sámi region (Alajärvi 2016).

As with the 2017 Deatnu Agreement, the Sámi opposition to the Arctic Railway has been sweeping and includes the Sámi Parliaments, the Sámi Council, Sámi organizations and reindeer herding districts. The presidents of the three Sámi Parliaments went as far as to reach out to the Foreign Minister of Singapore, asking him to spearhead Sámi and Indigenous rights at the Arctic Council where Singapore has an observer status (Holmestrand and Idivuoma 2017). In September 2018, a protest called the Red Line was organized in Sámi regions Vuohčču and Anár in coalition with Sámi and other Indigenous activists, youth, reindeer herders, and Greenpeace. In the event, a red line of people and banners was drawn along the proposed railway route to oppose the construction without the free, prior and informed consent of the Sámi people (Suoninen 2018). The Sámi Parliamentary Council issued a statement according to which the Sámi have not been adequately consulted or their views taken account of in the Arctic Railway planning (Sámi parlamentáralaš ráđđi 2018).

The most recent blow to the state's already deficient consultation practices took place in March 2019, when the 2011 Mining Act of Finland was amended to make it easier for mining companies to apply for an initial permit without an environmental impact assessment. Amended in a hasty manner, the Sámi Parliament was this time not asked for their input at all (Paltto 2019). Various UN bodies have, for several years, criticized the Nordic countries for their inadequate protection of the Sámi people's right 
to their lands and traditional livelihoods, lack of meaningful consultation and failure to obtain their free, prior and informed consent. The Committee for the Elimination of Racial Discrimination, for example, has urged Finland to uphold international norms and its own laws and constitutional obligations toward the Sámi people (CERD 2012; CERD 2017; Hirvasvuopio 2016).

Another major conflict that has deteriorated Sámi confidence in the state's intentions is the dispute over legal Sámi definition in Finland. The conflict originates from the proposed 1990 Sámi Act, discussed in the next section, and the consequent 1995 Act on the Sámi Parliament. This protracted conflict involves, among others, the state failing to comply with and unlawfully interfering the Sámi people's right to determine their identity and membership as part of their right to self-determination, as stipulated in the UN Declaration on the Rights of Indigenous Peoples. ${ }^{10}$ Since 2015, the Supreme Administrative Court of Finland has been approving individuals into the Sámi electoral roll to the elections of the Sámi Parliament against the will of and decisions by Sámi political bodies. Finland was admonished on these grounds by the UN Human Rights Committee in 2019 for violating the rights of the Sámi people (Human Rights Committee 2019).

The current political and legislative climate in which the Government of Finland seeks reconciliation with the Sámi makes many Sámi deeply suspicious of the sincerity of the government's intentions. Rather than rectifying the settler colonial logic of elimination of the Sámi, it appears to be continuing - if not intensifying - this logic through legislative processes and destructive infrastructure initiatives. Notwithstanding strong support in principle for the reconciliation process (Juuso 2018), many Sámi are uncertain whether they will participate in the TRC, concerned that it may serve as a means to gain Sámi approval for the various development projects while forgiving the state for its past wrongs. Others surmise that Finland has embarked on the TRC process to consolidate its international reputation as a democratic country respecting human and Indigenous rights - in the face of repression at the home front. ${ }^{11}$ One Sámi participant in the pre-TRC hearings reflected:

There are big questions like the [amendment of] the Act on the Sámi Parliament and the Arctic Railway, before we can decide about this [TRC]. It says a lot about state intentions. A TRC process requires trust which we do not have much. In my view, the Arctic Railway is a big dilemma; that [the former prime minister] Sipilä has approved it while the objective of this [TRC] process is to put an end to colonialism. It's totally crazy to seek a railway through our lands and at the same time we need to start reconciling. I do not know what is the biggest threat at the moment, is it that the state seeks reconciliation? So that in the future, if something goes wrong with the Sámi, they can say, "but we have reconciled and apologized." (cited in Juuso 2018, p. 22).

As scholars have noted, exclusion and inclusion serve as twin strategies of settler colonialism, intended to eliminate, incorporate or suppress Indigenous people "to the

\footnotetext{
${ }^{10}$ On the conflict, see Junka-Aikio (2016) and Lehtola (2016). On the Supreme Administrative Court consideration of the Sámi definition, see Labba (2018).

${ }^{11}$ The Constitution of Finland defines the state's role as the international guardian of peace and human rights.
} 
settler sovereign order" (Macoun and Strakosch 2013, p. 429). Working in tandem, they confine and restrict political resistance, effectively co-opting opposition and "immoderate" demands.

In Finland, there is a pattern of state co-optation of "excessive" requests on behalf of the Sámi. In the early 1970s at the height of the global civil rights movement, there was a desire to establish a national Sámi organization in Finland especially among the generation of young, educated Sámi. The growing demands of the Sámi movement and the pressure it created propelled the state into action to solve the "Sámi question" by containing it. The strategy of inclusion was to establish an assembly called the Sámi Delegation, the predecessor of the Sámi Parliament, in 1972. Looking back, the swiftness into action appears unusual in Finland's track record of neglect and general protracted conduct vis-à-vis Sámi affairs. One can only speculate that it was a lesser bad of the two options on the table, the other being a Sámi NGO at the national level (Lehtola 2005). The legal position of the Sámi Delegation was left ambiguous; it was neither an ordinary state authority nor an organization subject to private law (Myntti 2000). Through inclusion and incorporation, the Sámi interests were effectively contained and channeled away from their priorities toward a less antagonistic "solution" (cf. Strakosch 2015, p. 98).

There is a blurred line between inclusion and exclusion, but both are powerful colonizing practices. Inclusion, not to be mistaken either for Indigenous decolonization or for self-determination, is an effective mechanism of Indigenous domestication, and policy-making is one of its key sites. The critical analysis of Indigenous domestication through policy-making has largely focused on the past. Policy-making, however, continues to serve as a settler colonial strategy in contemporary settings as a way of asserting settler sovereignty and jurisdiction (Strakosch 2015).

Looking at Finland's tacit Sámi policy and its explicit legislative action in the past decade, it is not difficult to view state engagement in a truth and reconciliation process as part of the continuum in the settler colonial logic of elimination. There has been no court challenge obliging the government to establish a TRC. Nor has there been a rupture in policy-making and administrative practices that would signal the beginning of a new era and building greater trust among the Sámi toward the state. Particularly the process of leading to the amended Metsähallitus Act, a prime example of the twin approach of inclusion and exclusion, it also represents the classic Finnish ad hoc policy-making on Sámi issues. If it is true, as the former president of the Sámi Parliament Sanila-Aikio suggests, that the Sámi rights section was dropped from the 2016 Metsähallitus Act in order to pave way for the Arctic railway, there is very little hope for the Sámi in Finland in the reconciliation process with the state beyond becoming another example of channeling the Sámi away from their priorities toward more acceptable structures and outcomes.

In the same way it has happened in other settler colonial contexts such as Canada, the TRC in Finland may end up providing support for state objectives of closure, legitimating its sovereignty and official narrative of past wrongs rather than meeting goals and expectations established and articulated by the Sámi: land and resource rights, legislation, Sámi history in Finland, living conditions in Sápmi, boarding school experiences and assimilation.

Where the proposed TRC in Finland radically departs, however, from many of its counterparts is that the draft mandate negotiated between the government and the Sámi Parliament explicitly proposes to examine and address contemporary injustices and 
harms and specifically, to commit to structural change. Whether and how this will take place is to be seen. If we take the recent statement by the Minister of Interior as an any indication, there is nevertheless a tendency on the government side to focus on the past. In her view, the objective of the TRC is to examine the state responsibility of historical wrongs and through a dialogue, carve a path toward reconciliation (Wesslin and Rasmus 2019). In the last section of the article, I consider the prospects of structural reconciliation in Finland, and its chances to disrupt its "temporal narrative of slow progress away from colonization” (Macoun and Strakosch 2013, p. 428).

\section{Structural Reconciliation}

Political theorist Catherine Lu suggests that in order for practices of justice and reconciliation be meaningful and efficacious, we need to account for both interactional and structural forms of injustice. With most TRCs and other reconciliation initiatives, the focus has largely been on interactional justice that "refers to the settling of accounts between agents for wrongful conduct or unjust interactions and for undeserved harms" (Lu 2017, p. 19). Interactional justice seeks to correct and rectify the historical wrongdoings and relations between victims and perpetrators by creating platforms for sharing victims' painful experience and demanding compensation. This is, however inadequate, because there is tendency to depoliticize justice and reconciliation "in ways that are normatively and politically obscuring" (Lu 2017, p. 16). Reconciliation is depoliticized, for example, when we focus on "individual psychological healing from traumatic experiences" or when strategies invoke "an unrealistic and undesirable form of conflict-denying social unity that, in reality, serves to pressure the politically weak to accommodate evil and injustice" (Lu 2017, p. 183).

Efforts to achieve justice in contexts of social and political harm must address foundational problems of structural injustice, which include "the institutions, norms, practices, and material conditions that played a causal or conditioning role in producing or reproducing objectionable social positions, conduct, or outcomes" (Lu 2017, p. 19). Colonialism is another form of structural injustice, and a complete account of colonial structural injustice requires examining the social contexts of relations in which the wrongdoings took place ( $\mathrm{Lu} \mathrm{2017,} \mathrm{p.} \mathrm{142).} \mathrm{With} \mathrm{regard} \mathrm{to} \mathrm{doing} \mathrm{justice} \mathrm{vis-à-vis}$ Indigenous peoples, Lu argues that it is imperative to historicize contemporary accounts of structural injustices for it "helps to identify what might be objectionable about contemporary social structures" (Lu 2017, p. 157). As an example, the ongoing denial of Indigenous self-determination cannot be adequately understood as a form contemporary structural injustice without a historical understanding of Indigenous peoples' coercion and forcible incorporation into the nation states. Lu argues: "It is only by appreciating the specific nature and quality of historically objectionable political relations between indigenous groups, and settler and colonial groups, that we can arrive at an accurate diagnosis of some contemporary structural injustices" (Lu 2017, p. 158).

Yet settler colonial states and the common political discourse tend to prefer "noninstitutional, non-structural, interpersonal approaches to reconciliation" (Grey and James 2016, p. 322). Reconciliation processes pertaining to Indigenous peoples frequently overlook "the abusive colonial structure itself" and instead, focus on Indigenous individuals and groups overcoming legacies of past injustice (Coulthard 2014, p. 109). 
Reconciliation, in such contexts, implies Indigenous peoples reconciling into a political and legal order "that places them in a continued position of structural indignity" (Lu 2017, p. 200). Indigenous peoples are, therefore, being "reconciled to a contemporary injustice" (ibid.). For Lu, "structural dignity is a fundamental prerequisite of a just social structure and an objective component of structural reconciliation" (ibid.). In light of the unilateral incorporation into the state, structural dignity for Indigenous peoples requires special reparative measures, such as a greater share of resources, and arrangements that exceed democratic equality and instead, enable and facilitate collective self-determination. She explains:

If the historic destruction of indigenous governance, language, and culture continues to have structural effects for contemporary agents, then redressing such structural injustice requires devoting resources to alleviating these contemporary structural effects of genocide and settler colonialism. Repairing such enduring injustices even justifies departures from liberal neutrality, since the revival of indigenous languages and cultures may be a precondition for indigenous peoples to enjoy fair opportunity for self-determination in contemporary societies. ( $\mathrm{Lu}$ 2017, p. 174).

In addition to interactional reconciliation including the examination of the past and present wrongdoings experienced by the Sámi people, the proposed mandate for the truth and reconciliation commission in Finland commits to "structural change" and "interaction based on trust" (Valtioneuvoston kanslia 2019). One of its main objectives is for the Finnish state to take responsibility and be accountable for its wrongdoings and, together with key Sámi political organizations, strengthen the implementation of Sámi rights in Finland. Below, I consider what needs to happen in the Finnish Sámi policy-making to amount for structural reconciliation as discussed by $\mathrm{Lu}$.

A structural change in Finland would require a radical departure from the long-standing political disregard of Sámi rights and protections recognized in international law and noncompliance of its own legislated obligations. It would imply both amending existing and drafting new legislation in alignment with the minimum international norms pertaining to Indigenous rights, as well as providing resources and possibilities to adequately implement them. First and foremost, a structural change in Finland would require ensuring that the Sámi have genuine and meaningful capacity to govern the central aspects of their society and culture, which inseparably include land rights and land use practices. As the basic human right, the Sámi have a right to practice their culture that includes traditional livelihoods such as reindeer herding (Smith 2011; Smith et al. 2006).

At the very minimum, Indigenous peoples' right to self-determination entails the right to effectively and adequately to participate in decision-making involving issues affecting them and their societies. In Finland, this right currently exists only informally and even as such, is not properly observed. A minimal structural change would require amending the consultation requirement in the Act on the Sámi Parliament (974/1995, Art. 9) to include the international norm of free, prior and informed consent which forms "an integral part in the implementation of Indigenous peoples' right to self-determination” (Heinämäki and Kirchner 2017, p. 230). This would ensure the Sámi a real role in determining economic, social and cultural development in their home region.

Considering the centrality of collective self-determination for structural reconciliation regarding Indigenous peoples and the centrality of land rights for Indigenous self- 
determination, a key piece of legislation that would require a complete overhaul is the Act on the Sámi Parliament (974/1995) that stipulates the scope of Sámi “cultural autonomy" in Finland. ${ }^{12}$ The Act is a compromise of a 1990 legislative proposal that sought to address Sámi rights in Finland in a comprehensive manner. The proposed Sámi Act provided a framework that would have restored the Sámi people's rights to land, resources and traditional livelihoods in the Sámi region and safeguarded the development and their language, culture, and social conditions. The underlying premise of the proposed legislation was that since the Finnish state had not conclusively proven its title or ownership to the Sámi territories or that the Sámi title to their territories had been extinguished, the lands owned and formerly governed by the Sámi are to be returned. Most of the proposed Act's 27 articles focused on land use and the reorganization of land ownership and management in the northernmost Finland. A central proposition was that the lands and waters would be returned to siidas that were to be reconstituted and collectively owned by the Sámi under the proposed legislation (Saamelaisasian neuvottelukunta 1990).

The proposed Sámi Act was met with vehement opposition by a range of ministries, bodies and organizations, including the Ministries of Justice, Environment, Agriculture and Forestry, Metsähallitus, Ohcejohka/Utsjoki municipality (the only municipality in Finland where Sámi form a numerical majority), Lapland Provincial Administration and several other regional institutions (Sillanpää 1994). As the result of the major backlash, the proposal was withdrawn and a compromise limited to Sámi "cultural autonomy" was put forward, recognizing the Sámi right only to their language and culture. The legislation was passed as the Act on the Sámi Parliament together with the constitutional recognition of the Sámi as an Indigenous people in Finland in 1995.

Under the Act, the Sámi Parliament was established to administer and implement "cultural autonomy". Beyond internal matters such as hiring its own staff and allocating annual funding for Sámi related initiatives, the Sámi Parliament has no decision-making authority and cannot be called a self-government body (Kuokkanen 2019). A recent study shows that even in its constrained form, legislation pertaining to Sámi "cultural autonomy" has not been adequately implemented and that since 2003, the development has been mostly negative (Guttorm 2018). This has led to a perception among some Sámi that the Sámi Parliament represents an arm of the state's repressive policies (Juuso 2018, p. 26). What is more, when discussing Indigenous self-determination, there is a need to bear in mind that "no meaningful political autonomy is possible without a distinct territorial base for the population" (Sanders 1986, p. 20). ${ }^{13}$ Ethnic minorities may claim cultural and linguistic rights, but any form of political self-determination necessitates a jurisdictional boundary.

\footnotetext{
12 The amendment of the Act on the Sámi Parliament has been on the formal political agenda already twice in the 2010s. Both times the focus was on revising the legal definition of the Sámi, as per the request by the Sámi Parliament. The first proposal for an amended act fell through in 2015, when the great majority of the Finnish Parliament voted to retain the existing definition. The second proposal was rejected by the Sámi Parliament in 2018 due to the deficient consultation process. The amendment of the act has been identified as the top priority of the newly elected Sámi Parliament inaugurated in early 2020 (Saijets and Rasmus 2020).

${ }^{13}$ Some scholars have sought to decouple Indigenous self-government from territoriality, for instance, by referring to the model of urban reserves. It has been suggested that the control over a specific territory "should not be viewed as a normative precondition for self-government, self-determination or nationhood" (Dubois 2011, p. 1). Yet the relationship with the land is the founding feature even in such models: "It is not the reserve, as a place, that characterizes the nation, but rather their sense of belonging towards the land as well as towards the members of a group who are both on and off the reserve, that characterizes them as a nation and that legitimizes their claim to self-determination" (Dubois 2011, p. 4).
} 
The authority of institutions of cultural or non-territorial autonomy — such as Sámi "cultural autonomy" in Finland - is largely symbolic in substance (cf. Bauböck 2004; Coakley 2016).

Structural reconciliation in Finland would further require reversing the established practice of negotiating in bad faith which has been a hallmark of several governments in Finland. In recent years, it was particularly striking in the process leading to the lastminute collapse of an agreement between the government and the Sámi Parliament in 2015 to ratify the ILO Convention 169 (Markelin 2017). Since the proposed 1990 Sámi Act, there has been a host of state commissioned reports and committees inquiring into the Sámi land title, ownership and land use, all of which have been quietly shelved but frequently considered and endorsed as progress by state officials.

Finally, structural justice and dignity for Sámi in Finland would involve a fundamental shift in public and political discourses and attitudes that actively resist any recognition of Sámi rights. Political bodies both at the national and regional level would need to transform their deeply ingrained culture of institutional hostility and opposition to the idea and norm of Sámi self-determination and gain a basic understanding of the meaning of the status of the Sámi as an Indigenous people. This includes a shift from the nearly universal conception of the Sámi people as merely constituted by a culture in need of maintaining, rather than as a people with their own society and institutions. This is a precondition for understanding the historical fact that the Sámi, like other Indigenous peoples, have been forcibly incorporated into the settler colonial states and integrated into the state structures as individuals, without the recognition of their collective rights or status as a distinct people (e.g., Minde 2005; Olsson and Lewis 1995).

In order for structural reconciliation called for in the proposed TRC mandate occur, the entire political system in Finland would need to acknowledge - and act upon - Lu's conclusion that repairing enduring structural injustices requires a break from a stance of liberal neutrality, and allocation of resources to negotiate processes of structural change with the Sámi people. As Sheryl Lightfoot notes, reconciliation requires from the states "a credible commitment to change its future power relations and give up a certain degree of real, material, and political power in exchange for a new, renegotiated, more just and legitimate relationship with Indigenous peoples" (Lightfoot 2015, p. 36). This entails renegotiation and ongoing conversation about institutional arrangements and political orders between Indigenous peoples and settler states.

It is too early to estimate whether structural transformation will take place as the result of the TRC at the political, policy and legislative institutions in Finland. After nearly 3 years of negotiating the terms and preparing for a truth and reconciliation process, there has been no sign of change yet. It is to be seen whether the wish of the outgoing president of the Sámi Parliament - that Finland's Indigenous-friendly stance at intergovernmental bodies would finally translate into concrete measures in support of Sámi rights at the home front (Aikio 2020) - becomes a reality as the result of the TRC process in Finland.

\section{Conclusion}

The Sámi people have long called for a public process that would provide a collective platform for telling their experiences of Nordic colonialism, and in that way, expose the truth of the states' assimilationist policies in the past and present. Consequently, the Nordic countries have embarked on the path of reconciliation with the Sámi people, with Norway 
already having established a truth and reconciliation committee in 2018, Finland in the process of setting one up and Sweden re-commencing negotiations with the Sámi Parliament. This article has examined the TRC process in Finland, where the government and the main Sámi political bodies recently agreed on a mandate for a commission. Whereas most Sámi express at least qualified support for a TRC, there is widespread mistrust toward the government of Finland and its intentions in seeking reconciliation with the Sámi in a political climate considered deteriorating if not repressive, the state backsliding from already established rights, such the legislated duty to consult the Sámi on affairs impacting them.

In the current regressive political climate, there is confusion among many Sámi with regard to the supposedly oppositional processes of exclusion and inclusion of the state. I have drawn on settler colonial theory to analyze the seeming distinction between progressive and retrograde policy making in Finland - reconciliation on the one hand, weakening protections to Sámi livelihoods on the other. I argue that this apparent contradiction is false; in the context of recent measures and initiatives, reconciliation is a central tool of settler colonial policy making. The Sámi policy-making in Finland has long followed a trajectory of ad hoc measures and decision-making without collaboration between ministries and institutions, and also often without adequate knowledge of Sámi affairs or established legislation and regulations. Yet even if there has not been a prescribed Sámi policy, it is apparent that the ethos behind haphazard decision-making and steadfast hostility and inaction are informed by the settler colonial logic of elimination that seeks to assimilate and incorporate the Sámi into the state and its institutions.

In the final section, the article discussed the parameters of structural reconciliation vis-àvis Indigenous peoples and considered what it would entail in the Finnish context. According to Lu, structural justice for Indigenous peoples centres on responding to colonial injustice, which involves, first and foremost, providing resources and meaningful opportunities to facilitate and enact collective self-determination. In Lu's account, for Indigenous peoples who have been historically incorporated into the state without their consent, structural dignity, justice and reconciliation would entail reparative measures and arrangements not limited to democratic equality and which would facilitate collective self-determination.

Drawing on my analysis of Finland's track record of and ongoing Sámi policy, I have suggested that it is unlikely that the TRC will succeed in bringing such a fundamental foundational shift needed for structural change and reconciliation. The process in the past 3 years leading toward establishing a truth and reconciliation commission shows no sign of a departure from the assimilationist policies. Therefore, the Sámi may well be reconciled into a contemporary injustice as the consequence of the TRC in Finland. As settler colonial policy making, reconciliation then represents a continuation and extension of the colonial order, subtly entrenching existing injustice and reaffirming and legitimating state control.

\section{Funding Information Open access funding provided by University of Lapland.}

Open Access This article is licensed under a Creative Commons Attribution 4.0 International License, which permits use, sharing, adaptation, distribution and reproduction in any medium or format, as long as you give appropriate credit to the original author(s) and the source, provide a link to the Creative Commons licence, and indicate if changes were made. The images or other third party material in this article are included in the article's Creative Commons licence, unless indicated otherwise in a credit line to the material. If material is not included in the article's Creative Commons licence and your intended use is not permitted by statutory 
regulation or exceeds the permitted use, you will need to obtain permission directly from the copyright holder. To view a copy of this licence, visit http://creativecommons.org/licenses/by/4.0/.

\section{References}

Aikio P (1987) Experiences drawn from the Finnish Sámi Parliament. In: IWGIA (ed) Self Determination and Indigenous Peoples: Sámi Rights and Northern Perspectives. IWGIA, Copenhagen, pp 91-102

Aikio A (2015) Suomi sai nuhteita YK:n alkuperäiskansojen oikeuksien erityisraportoijalta "Metsähallituslakiluonnos uhkaa saamelaisten oikeuksia". yle.fi. https://yle. fi/uutiset/osasto/sapmi/suomi_sai nuhteita ykn alkuperaiskansojen_oikeuksien erityisraportoijalta metsahallituslakiluonnos_uhkaa_saamelaisten_oikeuksia/8539451. Accessed in 11 Dec. 2019

Aikio J (2020) Olgoministtar Haavisto mielas eamiálbmotáššiide lea buorre váikkuhit ON ja EU bokte. Yle Sápmi. https:/yle.fi/uutiset/osasto/sapmi/olgoministtar_haavisto_mielas_eamialbmotassiide_lea_buorre_ vaikkuhit_on_ja_eu_bokte/11203758. Accessed in 22 Apr. 2020

Aikio K, Näkkäläjärvi P, Satokangas G (2016) Tenon uusi sopimus loukkaa perustuslaillisia oikeuksia Utsjokelaisten eriävä mielipide. Yle Sápmi. https://yle.fi/uutiset/3-8998183. 28 Oct. 2019

Alajärvi M (2016) Sanila-Aikio: "Ruovdegeaidnu Jieknamerrii duođalaš sivva sámečuoggáid sihkkumii meahciráđđehuslágas”. yle.fi. https://yle.fi/uutiset/osasto/sapmi/sanila-aikio_ruovdegeaidnu_jiekamerrii_ duoalas_sivva_samecuoggaid_sihkkumii_meahciraehuslagas/8758120. Accessed in 16 Jan. 2020

Balandier G (1966) The colonial situation: a theoretical approach. In: Wallerstein I (ed) Social Change: The Colonial Situation. John Wiley \& Sons, New York, pp 34-61

Barrios V (2017) The construction of truth and the silence of responsibility: a discourse analysis on the idea of justice and a Sami Truth Commission. Uppsala University

Bauböck R (2004) Territorial or cultural autonomy for national minorities? In: Dieckhoff A (ed) The politics of belonging: Nationalism, liberalism and pluralism. Lexington Books, Lanham, pp 221-258

Benton D (2018) Finland becomes most attractive jurisdiction for mining investment. miningglobal.com. https://www.miningglobal.com/operations/finland-becomes-most-attractive-jurisdiction-mininginvestment. Accessed in 13 Feb. 2020

Björn N, Sjögren D (2019) Educational history in the age of apology: the Church of Sweden's "White book" on historical relations to the Sami, the significance of education and scientific complexities in reconciling the past Educare - Vetenskapliga skrifter 1:69-95

Byrd JA (2014) Follow the typical signs: settler sovereignty and its discontents Settler Colonial Studies 4:151154

CERD (2012) Concluding observations on the twentieth to twenty-second periodic reports of Finland, adopted by the Committee at its eighty-first session (6-31 August 2012). Committee on the Elimination of all Forms of Racial Discrimination, Geneva

CERD (2017) Concluding observations on the twenty-third periodic report of Finland. Committee on the Elimination of Racial Discrimination, Geneva

Coakley J (2016) Conclusion: patterns of non-territorial autonomy Ethnopolitics 15:166-185

Corntassel J, Holder C (2008) Who's sorry now? Government Apologies, Truth Commissions, and Indigenous Self-Determination in Australia, Canada, Guatemala, and Peru Human Rights Review 9: 465-489

Coulthard G (2014) Red skin, white masks: rejecting the colonial politics of recognition. University of Minnesota Press, Minneapolis

Dubois J (2011) Beyond territory: revisiting the normative justification of self-government in theory and practice. Int Indigenous Policy J 2

Finnish Transport Agency (2018) Arctic Ocean railway report. Finnish Transport Agency, Helsinki

Grey S, James A (2016) Truth, reconciliation, and double settler denial: gendering the Canada-South Africa analogy Human Rights Review 17:303-328

Griffiths K (2018) Hegemony and reconciling Indigenous-state relations. A discourse analysis of truth commission debates in Australia and Norway. Universitetet i Sørøst-Norge

Guttorm J (2018) Saamelaisten itsehallinto Suomessa - dynaaminen vai staattinen? PhD thesis. Lapin yliopisto, Rovaniemi

Hall C (2016) Sanningskommission för Sveriges samer : en studie om förväntningar och andra urfolks erfarenheter på väg mot upprättelse. MA thesis, Uppsala University, Uppsala

Heinämäki L, Kirchner S (2017) Assessment on recent developments regarding Indigenous peoples' legal status and rights in international law: with special focus on free, prior and informed consent. In: 
Heinämäki L et al. (eds) Saamelaisten oikeuksien toteutuminen: kansainvälinen oikeusvertaileva tutkimus. Valtioneuvosto, Helsinki, pp 224-282

Hirvasvuopio S (2016) YK moittii Suomea ja Ruotsia saamelaisasioista. Yle.fi. https://yle.fi/uutiset/38777708. Accessed in 11 Dec. 2019

Holmberg A (2018) Bivdit luosa - to ask for salmon. Saami traditional knowledge on salmon and the river Deatnu in research and decision-making. MA thesis, UiT The Arctic University of Norway, Tromsø

Holmestrand AB, Idivuoma M (2017) Mannet Singaporii bissehit Finnmárkku ruovdemáđiija. nrk.no. https:/www.nrk.no/sapmi/samedikkii-ministarat-ohcet-veahki-singapores-1.13591170. Accessed in 16 Jan. 2020

Human Rights Committee (2019) Views adopted by the Committee under article 5 (4) of the optional protocol, concerning communication No. 2668/2015. United Nations, Geneva

Junka-Aikio L (2016) Can the Sámi speak now? Deconstructive research ethos and the debate on who is a Sámi in Finland Cultural Studies 30:205-233

Juuso Á (2018) Sámi áššiid soabadanproseassa. Gullanraporta. Saamelaisten asioita koskeva sovintoprosessi. Kuulemisraportti. Valtioneuvoston kanslia, Helsinki

Kauanui JK (2016) “A structure, not an event”: settler colonialism and enduring indigeneity Lateral. J Cult Stud Assoc 5

Korpijaakko K (1989) Saamelaisten oikeusasemasta Ruotsi-Suomessa. Oikeushistoriallinen tutkimus LänsiPohjan Lapin maankäyttöoloista ja -oikeuksista ennen 1700-luvun puoltaväliä. Lakimiesliiton kustannus, Helsinki

Korpijaakko-Labba K (2000) Saamelaisten oikeusasemasta Suomessa. Kehityksen pääpiirteet Ruotsin vallan lopulta itsenäisyyden ajan alkuun. Sámi Instituhtta, Guovdageaidnu

Kuokkanen R (2019) Restructuring relations: Indigenous self-determination, governance and gender. Oxford University Press, New York

Kuokkanen R (2020) The Deatnu agreement: A contemporary wall of settler colonialism settler colonial studies

Labba O-A (2018) Kokonaisharkinta korkeimman hallinto-oikeuden vuosikirjapäätöksissä koskien saamelaismääritelmän tulkintaa. MA thesis. Lapin yliopisto, Rovaniemi

Lehtola V-P (2002) The Saami siida and the Nordic states from the middle ages to the beginning of the 1900s. In: Karppi K, Eriksson J (eds) Conflict and Cooperation in the North. University of Umeå, Umeå, pp 183202

Lehtola V-P (2005) Saamelaisten parlamentti. Suomen saamelaisvaltuuskunta 1973-1995 ja Saamelaiskäräjät. Sámediggi, Inari

Lehtola V-P (2016) Saamelaiskiista. Sortaako Suomi alkuperäiskansaansa? Into, Helsinki

Lightfoot S (2015) Settler-state apologies to Indigenous peoples: a normative framework and comparative assessment Native American and Indigenous Studies 2: 15-39

Lu C (2017) Justice and reconciliation in world politics. Cambridge University Press, Cambridge

Macoun A, Strakosch E (2013) The ethical demands of settler colonial theory Settler Colonial Studies 3:426443

Maddison S (2011) Beyond white guilt. Allen and Unwin, Sydney

Markelin L (2017) Uhattu kansa? Katsaus Suomen saamelaispolitiikkaan. Ajatushautomo Magma, np

Minde H (2005) Assimilation of the Sami - implementation and consequences Gáldu Č́la 3

Morgensen SL (2011) The biopolitics of settler colonialism: right here, right now Settler Colonial Studies 1: 52-76

Mustonen T (2016) Totuuskomissioista pohjoisessa. Snowchange Cooperative

Myntti K (2000) The Nordic Sami parliaments. In: Aikio P, Scheinin M (eds) Operationalizing the right of indigenous peoples to self-determination. Institute for Human Rights, Åbo Akademi University, Turku, pp 203-221

Nagy R (2012) Truth, reconciliation and settler denial: specifying the Canada-South Africa analogy Human Rights Review 13:349-367

Nahkiaisoja T (2006) Asutus ja maankäyttö Inarissa ja Utsjoella 1700-luvun puolivälistä vuoteen 1925. Oikeusministeriö, Helsinki

Nyyssönen J (2011) Principles and practice in Finnish national policies toward the Sámi people. In: Minnerup G, Solberg P (eds) First World, First Nations. Internal Colonialism and Indigenous Self-Determination in Northern Europe and Australia. Sussex Academic Press, Brighton, pp 80-96

Olsson SE, Lewis D (1995) Welfare rules and Indigenous rights: the Sami people and the Nordic welfare states. In: Dixon J, Scheurell RP (eds) Social Welfare with Indigenous Peoples. Routledge, London \& New York, pp 141-187

Osterhammel Jr (1997) Colonialism: a theoretical overview. Markus Wiener Publishers, Princeton, NJ 
Paltto A (2019) Suoma ruvkeláhka rievdaduvvoi - Stáhta álkida ruvkefitnodagaid lohppeohcánvuogádaga. Yle.fi. https://areena.yle.fi/1-50094420. Accessed in 16 Jan. 2020

Ranta K (2018) Ristenrauna Maggan perhettä nöyryytettiin kallonmittauksilla vielä 1960-luvulla Saamelaiset toivovat totuuskomission tuovan julki menneisyyden vääryydet. yle.fi. https://yle. fi/uutiset/3-10078361. Accessed in 18 April 2020

Rifkin M (2013) Settler common sense Settler Colonial Studies 3:322-340

Saamelaisasian neuvottelukunta (1990) Saamelaisasian neuvottelukunnan mietintö I. Ehdotus saamelaislaiksi ja erinäisten lakien muuttamiseksi. Sisäasiainministeriö, Helsinki

Saijets M (2018) Suomas boazodoalli ballá ruovdegeainnus - Ruoła sápmelaš rávve vuostálastit nu guhká go vejolaš. yle.fi. https://yle.fi/uutiset/osasto/sapmi/suomas_boazodoalli_balla_ruovdegeainnus_ruoa_ sapmelas_ravve_vuostalastit_nu_guhka_go_vejolas/10128067. Accessed in 16 Jan. 2020

Saijets M, Rasmus L (2020) Saamelaiskäräjälain uudistamista pidetään kuluvan kauden tärkeimpänä tavoitteena: yli puolet Saamelaiskäräjien jäsenistä priorisoi lakiuudistuksen. Yle.fi. https://yle. fi/uutiset/3-11228780. Accessed in 24 Apr. 2020

Sámi parlamentáralaš ráđđi (2018) Sámi parlamentáralaš ráđi cealkámuš Jieknameara ruovdegeaidnoprošeavttas vol 16 Jan. 2020. www.samediggi.fi. Accessed in 16 Jan. 2020

Sanders D (1986) Is autonomy a principle of international law? Nordic Journal of International Law 55:17-21

Selle P (2011) Sametingets organisatoriske utfordringer. En vurdering. Unpublished report

Sillanpää L (1994) Political and administrative responses to Sami self-determination. A comparative study of public administrations in Fennoscandia on the issue of Sami land title as an Aboriginal right. Societas Scientarum Fennica, Helsinki

Smith C (2011) The development of Sámi rights in Norway from 1980 to 2007. In: Minnerup G, Solberg P (eds) First world, first nations. Internal colonialism and Indigenous self-determination in Northern Europe and Australia. Sussex Academic Press, Brighton, pp 22-30

Smith C et al. (2006) Pohjoismainen saamelaissopimus. Suomalais-norjalais-ruotsalais-saamelaisen asiantuntijatyöryhmän 27. lokakuuta 2005 luovuttama luonnos. Oslo

Speed S (2017) Structures of settler capitalism in Abya Yala American Quarterly 69:783-790

Strakosch E (2015) Neoliberal Indigenous policy. Settler colonialism and the 'Post-Welfare' state. Palgrave Macmillan, London

Suoninen I-E (2017) Johtolat- ja diehtojuohkinministeriija ráđđádallá Jieknameara ruovdegeainnus Sámedikkiin ođđajagimánus - Sámediggi bivdán ráđđádallamiid juo geasset. yle.fi. https://yle. fi/uutiset/osasto/sapmi/johtolat-_ja_diehtojuohkinministeriija_raadalla_jiekameara_ruovdegeainnus samedikkiin_oajagimanus_samediggi_bivdan_raadallamiid_juo_geasset/9973688. Accessed in $1 \overline{6}$ Jan. 2020

Suoninen I-E (2018) Protesters in Finnish Sápmi draw red lines against railroad to Arctic Ocean. thebaretsobserver.com. https://thebarentsobserver.com/en/life-and-public/2018/09/finnish-sapmi-drawsred-line-against-railroad-arctic-ocean. Accessed in 17 Jan. 2020

Thisted K (2017) The Greenlandic Reconciliation Commission: ethnonationalism, Arctic resources, and postcolonial identity. In: Körber L, MacKenzie S, Westerståhl Stenport A (eds) Arctic Environmental Modernities. Palgrave Macmillan, Cham, pp 231-246

Tuck E, Yang KW (2012) Decolonization is not a metaphor Decolonization: Indigeneity, Education \& Society 1

Valtioneuvoston kanslia (2019) Saamelaisten totuus- ja sovintokomission asettaminen. Valtioneuvosto yhteistyössä saamelaiskäräjien ja kolttien kyläkokouksen kanssa. Valtioneuvoston kanslia, Helsinki

Veracini L (2010) Settler colonialism. A theoretical overview. Palgrave Macmillan, New York

Wall T (2019) The battle to save Lapland: 'First, they took the religion. Now they want to build a railroad'. theguardian.com. https:/www.theguardian.com/world/2019/feb/23/battle-save-lapland-want-to-buildrailroad. Accessed in 16 Jan. 2020

Wen P (2018) China unveils vision for 'Polar Silk Road' across Arctic. reuters.com. https://www.reuters. com/article/us-china-arctic-idUSKBN1FF0J8. Accessed in 16 Jan. 2020

Wesslin S, Rasmus L (2019) Duohtavuođa- ja soabadankommišuvnna nammadeami sáhttá stáhta beales álggahit - sisáššiid ministtar: "Suopma galgá guoddit historjjálaš ovddasvástádusa". yle.fi. https://yle. fi/uutiset/osasto/sapmi/duohtavuoa-_ja_soabadankommisuvnna_nammadeami_sahtta_stahta_beales alggahit_sisassiid_ministtar_suopma_galga_guoddit_historjjalas_ovddasvastadusa/11067978. Accessed in 17 Jan. 2020

Wolfe P (2006) Settler colonialism and the elimination of the Native Journal of Genocide Research 8:387-409

Publisher's Note Springer Nature remains neutral with regard to jurisdictional claims in published maps and institutional affiliations. 